\title{
ГРОМАДСЬКО-ПОЛІТИЧНА ДІЯЛЬНІСТЬ ПЕДАГОГІВ ШКІЛ УРСР У 1950-1980-Х РОКАХ
}

Анотація: Учительство у радянській державі розглядали у фокусі рупорів ідеології правлячої партії, котрі формували світогляд підростаючого покоління. Воно поставало і з позииій кадрової політики, яка носила чітко регламентований і централізований характер. На учительських зї̈здах працівників народної освіти та комісіях з питань освіти обговорювали питання різних сфер життя педагогів і наголошували на їх участі у них.

Ще одним напрямком їх діяльності стало долучення до передвиборчих кампаній. Вони виступали у ролі й агітаторів, акцентуючи на особливостях і перевагах радянської системи, $i$ кандидатів у депутати. Педагоги брали участь й у громадських заходах, приурочені річнииям життя та творчості діячів культури. Учителі були агітаторами, членами Педагогічного товариства з поширення політичних і наукових знань. Під гаслами соціально-економічного поступу СРСР педагоги допомагали на підприємствах, на ланах і фермах колгоспів і радгоспів. 3 одного боку, ці заходи демонстрували інтеграцію кожного у державотворчі процеси, а з іншого відривали учительство від його безпосередніх справ.

Ключові слова: вибори, громадсько-політична діяльність, педагоги, політика, суспільство, Українська РСР, учителі, школа

Показниками активності громадян є участь у житті суспільства. Вона може бути пасивною, може носити конструктивістський характер, коли через власну діяльність, виконуючи професійні обов'язки, особистість здійснює внесок у розбудову суспільства. Діяльність учительства при цьому є важливою. Протягом радянського періоду історії України його розглядали з позиції виконавців волі Комуністичної партії, яке беззаперечно підпорядковувалося їм. Вивчення питання громадської участі шкільної інтелігенції у житті Української РСР від 1950-х - до другої половини 1980-х років дозволить пролити світло на з'ясування добровільного або вимушеного виконання обов'язків, особистих прагнень, міжлюдських взаємовідносин. Науково-теоретична доцільність вивчення цієї проблеми доречна у процесі розвідок проблем загального курсу вітчизняної історії, історії радянського суспільства, інтелігенції, історії культури. Практична значимість можлива під час обговорення питань суспільного значення у контексті прийняття нормативно-правових документів різних сфер життя, підвищення престижу учительської праці та соціального захисту цієї професійної категорії.

Проблема діяльності учительства широко представлена в історичній науці. Педагогів розглядали як виконавців настанов керівної партії. До таких авторів належать

\footnotetext{
"Лаврут Ольга Олександрівна - кандидат історичних наук, доцент кафедри суспільно-гуманітарної освіти Донецького обласного інституту післядипломної педагогічної освіти, доцент (м. Краматорськ, Україна); ORCID: https://orcid.org/0000-0002-6915-7474; e-mail: lavrut.olga@gmail.com
} 


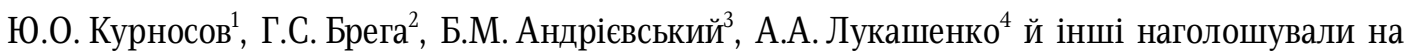
важливості їх якісної підготовки ${ }^{5}$. 3 педагогічних позицій В.Ф. Паламарчук ${ }^{6}$ і В.Ф. Шаталов зосередилися на впровадженні педагогічних ідей у практику роботи школи. В.О. Сухомлинський ${ }^{8}$ приділяв у своїх працях питанню суспільної ролі учителів. Н.С. Брехунець та І.С. Пхиденко9 зосередилися на функціонуванні закладів освіти у другій половині XX ст. і формуванні світогляду педагогів ${ }^{10}$. У роботах представлені лише окремі епізоди громадської діяльності ${ }^{11}$ учителів УРСР у $1950-\mathrm{x}$ - 1980-х років, що спонукає до поглибленого вивчення цього питання ${ }^{12}$. Завдання нашої роботи полягають у з'ясуванні питання участі педагогів у передвиборчих кампаніях і напрямах їх роботи; характеристиці діяльності осередків учителів, їх долученість до просвітницької та практичної роботи на підприємствах, колгоспах, радгоспах, організаціях. Важливим $є$ висвітлення ставлення учительства до цих заходів.

На педагогів покладалося завдання розкрити юному поколінню «всю красу комуністичних ідеалів», дати йому міцні основи знань, навчити вихованців діяти відповідно до досягнень комунізму. «Школа в нашій країні завжди була і буде предметом піклування Комуністичної партії». Радянський уряд посилався у своїй діяльності на праці В. Леніна, який розглядав учителів як апарат, який повинен просувати роботу, будити думку, боротися із пересудами. Він пропонував поставити педагога на таку висоту, на якій він ніколи не стояв у буржуазному суспільстві. Учителі ставали армійцями освітнього і

\footnotetext{
${ }^{1}$ Курносов Ю.О. Здійснення інтелігенцією України ленінських ідей науково-технічного прогресу // Український історичний журнал. 1970. № 8. С. 12-20; Курносов Ю.О. Інтелігенція УРСР та науково-технічний прогрес (1959-1970). Київ: Наукова думка, 1975. 207 с.

${ }^{2}$ Интеллигенция Советской Украины / под ред. Ю.А. Курносова; авт. кол.: Г.С. Брега, Н.Н. Варварцев, Н.В. Комаренко, Ю.А. Курносов, Л.П. Ткачева; АН УССР. Институт истории. Киев: Наукова думка, 1968. 190 с. ${ }^{3}$ Андриевский Б.М. Проблемы формирования состава педагогических кадров общеобразовательных школ (на материалах Украинской СССР): автореф. дис... канд. пед. наук: 13.00.01. Киев, 1974. 23 с.

${ }^{4}$ Лукашенко А.А. Піклування про вчителя - одне 3 головних завдань комуністичної партії в розвитку загальноосвітньої школи (на матеріалах Української РСР. 1959-1965 рр.) // Наукові праці з історії КПРС (Київ). 1968. Вип. 20. С. 194-201; Лукашенко А.А. Роль партійної організації України у підготовці вчительських кадрів у період семирічки // Наукові праці з історії КПРС (Київ). 1969. Вип. 9. С. 95-109.

${ }_{5}^{5}$ Злзюн I. А. Народний учитель у соціалістичному суспільстві // Радянська школа. 1986. № 1. С. 12-19.

${ }^{6}$ Паламарчук В.Ф. Системний підхід до впровадження педагогічних ідей у практику роботи школи // Радянська школа. 1986. № 12. С. 16-21.

${ }^{7}$ Шаталов В.Ф. За чертой привычного: ответы учителя-новатора на заданные журналистом Н. Столяровым вопросы о проблемах перестройки общеобразовательной школы. Донецк: Донбасс, 1988. 69 с.

${ }^{8}$ Сухомлинський В.О. Суспільство і вчитель. Твори в 5 томах. Київ, 1977. Т. 5. С. 2.

${ }^{9}$ Брехунещь Н.С. Навчальні заклади освіти України 50-80-х років XX століття: історіографія: автореф. дис... к. іст. н.: спец. 07.00.06. Київ, 2006. 25 с.; Пхиденко І. С. Світоглядна політика в освітянсько-виховному процесі України 70-х - першої половини 80-х рр. ХХ століття: автореф. дис... канд. іст. наук: 09.00.11. Київ, 2001. 20 c.

${ }^{10}$ Сворак С.Д. Загальноосвітня школа західноукраїнського регіону в контексті суспільно-політичного життя другої половини 40-х-першої половини 60-х років XX століття: автореф. дис... д-ра іст. наук: 07.00.01. Київ, 1999. $34 \mathrm{c}$.

${ }^{11}$ Касьянов Г. Незгодні: українська інтелігенція в русі опору 1960-1980-х років. 2-ге вид., випр. і доповн. Київ: ТОВ «Видавництво “Кліо”», 2019. 248 с.

${ }^{12}$ Елліс I.О. Образ учителя в суспільно-культурному житті пізньорадянського суспільства 70-80-х рр. ХХ ст.: автореф. дис... канд. пед. наук: 13.00.01. Харків, 2011. 20 с.
} 
ідеологічного фронту. «Численна армія радянських учителів 3 честю виконує свій громадянський обов'язок. Вона є великою культурною силою». Водночас, акцентували, що дорослі не можуть бути відірвані від громадського життя школи, комсомольської і піонерської організацій» ${ }^{13}$.

На Першому у післявоєнний час Всесоюзному учительському з'їзді (2-4 липня 1968 р.) делегати висловилися за активізацію громадської діяльності педагогів ${ }^{14}$. IV Всесоюзні педагогічні читання у березні 1976 р. були присвячені співдружності школи, сім'ї і громадськості у вихованні дітей та молоді15. На Всесоюзному з'їзді працівників народної освіти, який відбувся у грудні 1988 р. у м. Москві, обговорювали питання взаємодії школи та інших соціальних інституцій ${ }^{16}$. Учителі стали активними учасниками передвиборчих кампаній, зокрема 1958 р., нормативно-правовим підгрунтям чого став Указ Президії Верховної Ради СРСР від 28 грудня 1957 р., який зазначав, що у зв'язку із закінченням повноважень Верховної Ради СРСР четвертого скликання 14 березня 1958 р., на підставі статті 54 Конституції СРСР, Президія постановила призначити вибори до Верховної Ради СРСР на неділю 16 березня 1958 р. «Радянські люди сповнені надій на те, що 1958 рік принесе нові успіхи у справі миру, демократії і соціалізму. У нас є всі підстави впевнено дивитися в майбутнє. Комуністична партія і Радянський уряд зроблять усе, щоб наступаючий Новий рік був роком мирної праці для всіх народів, роком нових і нових успіхів нашого народу...». Про це писали у розпал «гонки озброєнь» ${ }^{17}$.

Указами Президії Верховної Ради СРСР було утворено 731 виборчий округ на вибори до Ради Союзу (у тому числі в Українській РСР - 152) і 633 виборчих округи на вибори до Ради Національностей (у тому числі в УРСР). Затверджено склад окружних виборчих комісій до Ради Національностей Верховної Ради СРСР. Виборці висунули до них значну кількість працівників освіти. Головами окружних виборчих комісій затверджено: у Житомирському виборчому окрузі завідувача Житомирським облВНО І.А. Харченка (від обласної організації профспілки працівників освіти, вищої школи і наукових установ), Кіровоградському окрузі - директора Кіровоградського педагогічного інституту Ф.Г. Овчаренка (від викладачів і студентів інституту), Тернопільському - М.Л. Бригінця (від обласної профспілки працівників освіти, вищої школи і наукових установ). Заступниками голів окружних виборчих комісій затверджені у Ворошиловградському виборчому окрузі К.Ю. Шелудченко - від Лисичанської міської організації профспілки, Дрогобицькому і Львівському виборчих округів - 3.С.Ярема і В.Д. Войтюк - від обласних організацій профспілок відповідно. Членів окружних виборчих комісій педагогів представляли

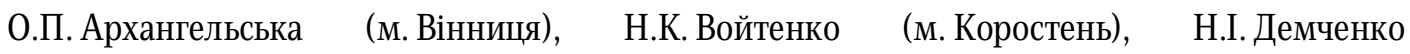
(Шевченківська районна організація профспілки працівників освіти, вищої школи і наукових установ м. Києва), Л.Я. Медяникова (м. Авдіївка), А.А. Козак (м. Станіслав), О.П. Ужва (м. Ужгород), А.С. Янчик $\quad$ (м. Сиваш), С.В. Кондратьєва $\quad$ (м. Кам'янець-

\footnotetext{
${ }^{13}$ Радянський учитель. Передова «Правды» за 16 січня 1958 р. // Радянська освіта. 1958. №3. С. 1.

${ }^{14}$ Бурова Е. Проблема взаємодії педагогічної теорії та освітянської практики у роботі вчительських з'їздів (5080-ті роки ХХ ст.) // Рідна школа. 2013. № 3. С. 37-43.

${ }^{15}$ Лаврут 0.0. Шляхи формування учительського світогляду «доби застою» в Українській РСР // Гілея: науковий вісник. 2018. Вип. 134. С. 120-125.

${ }^{16}$ Бурова Е. Вказ. пр.

${ }^{17}$ Указ президії Верховної Ради СРСР про вибори в СРСР // Радянська освіта. 1958. № 1. С. 1.
} 
Подільський), П.К. Стах (м. Михайло-Коцюбинський) та інші ${ }^{18}$.

Педагоги і службовці середніх шкіл № 2, i № 3 м. Дрогобича висунули кандидатами в депутати у Дрогобицькому виборчому окрузі Голову Президії Верховної Ради СРСР К.Є. Ворошилова і учительку середньої школи № 2 Ю.І. Дякун. На шпальтах періодичних видань акщентувалося, що в Раду мали прийти «справжні патріоти, які вірно будуть служити Батьківщині, стануть державними діячами». У ЗМІ писали, що в УРСР збори перетворювалися на яскраву демонстрацію морально-політичної єдності народу, його згуртованості навколо ленінського ЦК КПРС, цілковитого схвалення трудящими мудрої політики партії, яка веде «народ до торжества комунізму». Тематика виборів була актуальною протягом майже року. Привітання жінок зі святом 8 березня також відбувалося у цьому контексті ${ }^{20}$. у періодичних виданнях і по телебаченню наголошували, що участь жінок у державному житті можлива хіба що у країні Рад, на противагу західноєвропейським країнам і США 21.

Брати участь у виборах мали всі: «Не повинно бути жодного виборця, який не використав би почесного громадянського права обирати депутатів до Верховної Ради СРСР», зазначалося у зверненні ЦК КПРС. Закликали голосувати за кандидатів блоку комуністів і безпартійних. Учні-старшокласники, які досягли 18-річного віку, теж брали у цьому участь. Для роботи серед виборців у школах виділяли учителів-агітаторів. Зокрема, у Пологівській середній школі №1 Запорізької області такою була учителька-комсомолка Л.М. Голуб, яка ознайомлювала школярів $з$ особливостями та перевагами радянської виборчої системи ${ }^{22}$. У Повідомленні Центральної виборчої комісії по виборах до Верховної Ради СРСР про підсумки виборів 16 березня 1958 р. зазначалося, що у цілому в СРСР у них взяло участь 133836325 осіб, в УРСР - 27984894 особи (або 99,98\% загальної кількості виборців у республіці), з них 99,83\% голосували за кандидатів блоку комуністів і безпартійних до Ради Союзу і 99,86\% голосували за кандидатів блоку комуністів і безпартійних до Ради Національностей. У цілому в СРСР ці показники складали 99,7, 99,57 і 99,73\% відповідно ${ }^{23}$. На педагогічних радах шкіл заслуховували питання про завдання педагогічного колективу на час виборів до Народних судів, які відбулися 5 грудня 1957 р. У документах зазначалося про активну участь усього педагогічного колективу до підготовчої роботи, перепису виборців та інших заходів. Прикметно, що у протоколі № 4 педагогічної наради Балтської середньої школи № 3 Одеської області цьому відведено декілька рядків, більше уваги приділяли питанню успішності учнів ${ }^{24}$.

Педагоги долучалися й до обговорення питань різних сфер життя країни: соціально-

\footnotetext{
${ }^{18}$ До виборів у Верховну Раду СРСР. Працівники освіти у складі виборчих комісій // Радянська освіта. 1958. № 4. C. 1 .

${ }^{19}$ Назустріч виборам. Кандидати народу // Радянська освіта. 1958. № 6. С. 1.

${ }^{20}$ Робітницям і колгоспницям, діячам науки і техніки, освіти, літератури, мистецтва, охорони здоров'я, всім радянським жінкам! // Радянська освіта. 1958. № 10. С. 1.

${ }^{21}$ Казачкова Ю. Народний кандидат // Радянська освіта. 1958. № 10. С. 3.

${ }^{22}$ Костенко I. У Пологівській школі // Радянська освіта. 1958. №10. С. 4.

${ }^{23}$ Повідомлення Центральної виборчої комісії по виборах до Верховної Ради СРСР про підсумки виборів 16 березня 1958 року // Радянська освіта. 1958. №12. С. 1.

${ }^{24}$ Книга протоколів педагогічних рад учителів Балтської середньої школи за 1957/1958 н.р. 40 арк. // Державний архів Одеської області (ДАОО). Ф. Р-6994. Оп. 1. Спр. 31. Арк. 6.
} 
економічної, культурної. На Харківщині увага, так само як і в інших областях УРСР, була зосереджена на обговоренні рішень лютневого Пленуму ЦК КПРС, тез доповіді М.С. Хрущова про розвиток колгоспного ладу та реорганізацію МТС. Звісно, що педагоги одноголосно схвалювали ці документи, наголошуючи на своїй активній участі у виробничих процесах: весняній посівній кампанії, прополці, збиранню врожаю, доглядом за садами. Учителі читали колгоспникам лекції і доповіді, створювали концертні бригади та бібліотеки-пересувки ${ }^{25}$. У Брацлаві Вінницької області обговорювали виступ першого секретаря райкому партії А.О. Патія «Рішення лютневого Пленуму ЦК КПРС та завдання вчителів району», де звернули увагу на політехнічне навчання учнів, яке набуло обертів 3 кінця 1950-х - 1960-х рp. ${ }^{26}$

2 грудня 1958 р. у приміщенні залу засідань Київської міської ради депутатів трудящих відбулися збори активу вчителів, працівників освіти і трудових резервів м. Києва. На порядок денний були винесені «Тези ЦК КПРС і Ради Міністрів СРСР «Про зміцнення зв'язку школи 3 життям і про подальший розвиток системи народної освіти в країні» та завдання вчителів і органів народної освіти». Оскільки у заході брав участь Міністр освіти I.К. Білодід, зібрання носило формальний характер і зводилося до підтримки усіх починань держави. Педагоги були занепокоєні вибором дітьми фахів у школах, які виходили винятково $з$ потреб місцевості, а не потреб дітей, про що відзначила заслужена учителька школи УРСР В.А. Вікторовська. Ї̈̈ колега, учитель фізики середньої школи № 145 П.П. Солдатьонок, зазначив про необхідність змін методів навчання у напрямку розвитку самостійності та ініціативності, поділившись власним досвідом викладання предмета шляхом активізації занять на уроках.

Актуальними залишалися питання поліпшення виховання учнів у школах. Педагоги піднімали проблеми необхідності зацікавленості дітей в освітньому процесі, долучення до праці, формування комуністичного світогляду, пропонуючи створити спеціальні ілюстровані хрестоматії для старших класів. Питання кадрового забезпечення теж залишалися нагальними. Це стосувалося прав директорів шкіл щодо укомплектування педагогами, підготовки вихователів груп подовженого дня, оплати позакласної роботи. Завідувач міськВНО П.І. Островська окреслювала плани про розширення мережі шкіл за рахунок будівництва нових 50 приміщень і 23 шкільних будинків, що мало сприяти вирішенню питання про двозмінне навчання учнів ${ }^{27}$. Педагоги, які долучалися до роботи подібних заходів, отримували відповідні документи. Зокрема, Житомирський міський комітет КП України надав посвідчення Л.Ф. Бобровській про її обрання делегатом на XVII Житомирську міську партійну конференцію 3 правом вирішального голосу загальними зборами первинної парторганізації школи № 45 за підписом Житомирського міськкому КП України В. Удовицького. Посвідчення було дійсне при наявності партійного квитка ${ }^{28}$.

Задля демонстрації демократичних процесів в освітній сфері працювали комісії народної освіти, куди долучали депутатів та актив. Наприклад, до складу постійної комісії

\footnotetext{
${ }^{25}$ Іваненко Ю. Слово вчителів // Радянська освіта. 1958. № 12. С. 3.

${ }^{26}$ Рабінович П., учитель. Важливий захід // Радянська освіта. 1958. № 12. С. 3.

${ }^{27}$ На зборах вчителів м. Києва // Радянська освіта. № 18. С. 2.

${ }^{28}$ Біографічні матеріали про Бобровську Любов Федорівну (фотографії, мандати, посвідчення). 1962 р. // Державний архів Житомирської області (ДАЖО). Ф. Р-4655. Оп. 1. Спр. 1. Арк 4.
} 
народної освіти Полтавської міської ради депутатів трудящих входили 30 депутатів, серед яких науково-педагогічні працівники вищих навчальних закладів міста, директори й учителі шкіл. Вони мали постійні доручення та закріплені за окремими школами, дитячими садками і дитячими будинками. Комісія працювала за планом, який складався на квартал. На своїх засіданнях члени комісії розглядали такі питання: підготовка шкіл до «40річчя Великої Жовтневої соціалістичної революції», робота батьківських комітетів у школах, зв'язок педагогічних інститутів зі школами, підготовка шкіл до іспитів і нового навчального року, організація виробничого навчання у школах та інші. На засіданнях комісії присутніми були і члени виконкому міської Ради, інспектори відділу народної освіти, директори шкіл і дитячих будинків, науковці, голови батьківських комітетів, представники підприємств і організацій, які шефствували над школами. Комісія проводила свої засідання у школах, дитячих садках, інститутах, міськВНО, Палаці піонерів. Члени комісії вели активну пропаганду педагогічних знань. Серед них виділяли директора 20-ї школи міста - Глаголь, учителів Полтави - Колос і Толузакову. 3 ініціативи постійної комісії в більшості шкіл міста силами учнів, учителів, батьків і шефів обладнано майстерні, спортзали, теплиці, географічні майданчики. Увагу звертали і на дітей-сиріт, які отримали допомогу у сумі більше 60 тис. крб. Комісія опікувалася питанням здійснення охоплення освітою школярів. Все ж, запобігання правопорушень учнів у громадських місцях, працевлаштування випускників шкіл залишалися нагальними у діяльності комісії 29

Учителі брали участь і у громадських заходах, приурочені річницям життя і творчості діячів культури. Такою постаттю залишався Т. Шевченко. До Канева відправляли педагогів. Заслужений учитель УРСР І.К. Сидоренко згадував, що голова сільради с. Глинча відправив 10 осіб сільського активу для відвідування Тарасової гори. Виїхали з села вранці колгоспною підводою. Прибули до місця призначення приблизно об 11 годині. Були на Тарасовій горі люди і з інших сіл, але небагато. Він був здивований, що екскурсанти оглянули лише музей Т. Шевченка. Ні мітингу, ні самодіяльності не було. Незрозуміло, для чого звезли сюди людей. 0 4-й годині дня почали їхати назад додому. Тобто, захід нагадував формальність, але він був важливим у житті українців, і вони це розуміли ${ }^{30}$.

Учителі були агітаторами, членами Педагогічного товариства 3 поширення політичних і наукових знань. В областях Української РСР функціонували відділення Педагогічного товариства, які були покликані здійснювати політико-просвітню роботу серед педагогічної громадськості. Зокрема, Ровенське обласне відділення педагогічного товариства у 1965 р. провело засідання президії обласної ради товариства, пленум, наради, науково-практичні конференції з теми: «Шляхи піднесення якості навчання і виховання учнів», $з$ питань комуністичного виховання, батьківську конференцію - «Моральне виховання дітей в сім'ї» ${ }^{31}$. Педагоги поширювали політичні та наукові знання через «радянські народні університети», зокрема у 1962 р. у Херсонській області іх функціонувало 64, в тому числі і «Педагогічного товариства». Учителі долучалися до роботи клубів,

\footnotetext{
${ }^{29}$ Толстоносова Т. Постійна комісія народної освіти // Радянська освіта. 1958. № 4. С. 2.

${ }^{30}$ Сидоренко І.К. Життя у спогади сплелося. Бібрка. С. 18.

${ }^{31}$ Довідки та інформації про житлово-побутові умови, зростання ідейно-політичного рівня учителів Херсонської області і стан громадського харчування у школах. 1963 р. // Державний архів Херсонської області (ДАХО). Ф. Р-2296. Оп. 3. Спр. 253.Арк. 43.
} 
бібліотек, «червоних кутків», обласного огляду художньої самодіяльності. У фонді про Ю.М. Черненко, яка була членкинею «Педагогічного товариства УРСР», у зведених відомостях про його роботу у 1974-1978 рр. знаходимо інформацію про динаміку кількості членів товариства з 1974 до 1979 рр.: збільшилася кількість індивідуальних членів із 307536 осіб до 439 133, а юридичних - 17948 до 19794 осіб відповідно. Це товариство займалося і народними університетами педагогічних знань. В УРСР у зазначені роки працювало 3105 осередків, де налічувалося 7,6 млн. осіб і 3979 - 10,3 млн. відповідно 32 .

у доповіді голови товариства, академіка АПН СРСР М.Д.Ярмаченка, інформації заступника голови В.П. Вугрича про роботу Республіканської ради та виступах інших наголошувалося, що у рішеннях Пленуму ЦК партії, доповіді на ньому М.С. Горбачова поставлене завдання щодо оцінки реального стану справ у цих організаціях, виявити недоліки та вжити заходів щодо їх усунення і «...гідно зустріти XXVII зїзд КПРС». Певних успіхів досягли відділення Дніпропетровської, Кіровоградської, Івано-Франківської, Львівської, Миколаївської та інших областей. Голови обласних відділень: Донецького 0.О. Гладчук, Ровенського - В.Р. Дунай, Ворошиловградського - Н.О. Клочкова, Миколаївського - М.А. Рапопорт, Чернігівського - В.Г. Черненко, заступник голови Дніпропетровського відділення Л.П. Єльченко, член президії Республіканської ради Педтовариства О.Я. Савченко вказували на недоліки та шляхи їх подолання.

Одне із завдань діяльності Педагогічного товариства полягало у зміцненні та поліпшенні діяльності первинних організацій, що складали основу осередку, адже їхня робота часто зводилася до збирання членських внесків. При кожній такій організацій могли бути творчі групи і групи науково-педагогічної інформації, філіали народних університетів для учителів і батьків чи відповідні лекторії, консультпункти та кабінети педагогічної освіти батьків і секції. Первинна організація могла стати ініціатором різних заходів: педагогічних читань, зустрічей, читацьких конференцій, виставок, конкурсів, вечорів портретів і сімейних вечорів.

Ширшою мала бути мережа філіалів і факультетів університетів науковопедагогічних знань для класних керівників, вихователів ГПД, учителів праці, майстрів виробничого навчання, викладачів компіютерної техніки, та - 3 проблем навчання дітей шестирічного віку. Товариство вивчало та поширювало передовий педагогічний досвід. При республіканській, обласних і районних (міських) радах створені секції і громадські лабораторії з різних проблем педагогіки, а при первинних організаціях - групи науковопедагогічної інформащії та творчі групи. Вони пропагували досвід, проводили різні конкурси, влаштовували літературні виставки, вели картотеки видань тощо. Педагогічне товариство використовувало такі форми роботи: обласні зльоти учителів, педагогічні вогники, вечори-портрети, естафети передового досвіду, виставки, літописи шкіл, музеї і куточки історії освітніх закладів, випуски стінгазет, бюлетенів і публікації у місцевій пресі. Але не дивлячись на численні заходи, їх ефективність була низькою. Секції, лабораторії, творчі групи часто дублювали роботу відповідних установ та органів. Тому, необхідно було ліквідувати зазначене в організації роботи цих товариств та установ. Особливу увагу

\footnotetext{
32 Документи професорсько-викладацького складу учбових закладів і вчителів, 1913-1995 рр. Черненко Ю. М. // ДАХО. Ф. Р-4003. Оп. 6. Спр. 4. Арк. 1.
} 
осередків необхідно було звернути на проблеми трудового навчання та виховання i профорієнтації школярів, сімейного виховання дітей, переходу до навчання шестирічок, виховання «важких дітей», і в цілому - на вимогах шкільної реформи 1984 p. $^{33}$

Учителі займалися агітаційною діяльністю у колгоспах, підприємствах, організаціях. Педагоги на фермі колгоспів читали лекції та роз'яснювали рішення сесій Верховної Ради СРСР, рішення пленумів ЦК КПРС, читали доповіді про міжнародне становище: «Найкраще працювали вчителі-агітатори Г.С. Сироватко, Б.Р. Авраменко, Г.Г. Клеветенко, P.І. Бойко, які у польових бригадах колгоспу ім. М.С. Хрущова провели бесіди та випустили кілька польовок - стінних газет, недостатньо працювали вчителі-агітатори Л.Я. Сидоренко, O.М. Зевлевер, Г.З. Кравченко та деякі інші» ${ }^{34}$.

Особливо звертали увагу на молодих фахівців. Учительські колективи шкіл м. Кадіївки, Ровеньківського, Свердловського й інших районів Луганської області, наслідуючи приклад сімферопольського токаря Г.І. Яворського, який почав рух «поруч 3 тобою не повинно бути відстаючих», взялися допомагати молодим учителям. Подібний рух розгорнувся у багатьох школах Полтавської області. Республіканський комітет профспілки підтримав цю ініціативу та рекомендував усім профспілковим комітетам ознайомити учителів шкіл із зобов'язаннями луганчан, популяризувати іх. «Великий авторитет серед населення здобув учитель-агітатор M.I.Зозуля (Безпальчівська середня школа Гельмязівського району Черкаської області). Бесіди і лекції його завжди цікаві, бо тісно пов'язані із життям місцевого колгоспу, регіону та країни». Колгоспники зазначали, що такі лекції «допомагали їм розв’язувати ряд практичних питань організації своєї праці і побуту». Наголошували на посиленні уваги профспілкових організацій до організації відпочинку, культурно-масової та фізкультурно-оздоровчої роботи серед учителів і всіх працівників народної освіти, зокрема - до розвитку художньої самодіяльності ${ }^{35}$.

У доповідній записці з досвіду роботи з молодими вчителями органів народної освіти і комітетів профспілки Черкаської та Полтавської областей зазначалося, що учитель покликаний формувати у своїх вихованців комуністичну переконаність, громадську зрілість, суспільну і політичну активність, любов до праці, що потребувало від педагога високої ідейності, «...постійної творчості і самовідданості, душевної щедрості і доброти...». 3 цією метою у цих областях створені школи молодого вчителя, у планах роботи яких передбачені виступи керівників партійних, радянських, профспілкових органів, заслужених вчителів, відмінників народної освіти, працівників відділів народної освіти та керівників шкіл. Наприклад, у Золотоніському районі Черкащини було розроблене положення про школи, яке було затверджене на спільному засіданні ради районного відділу народної освіти та президії райкому профспілки. Безпосереднє керівництво здійснювала рада молодих учителів. Члени ради вивчали запити педагогів і надавали практичну допомогу у проведенні заходів. Заняття проводилися чотири рази на рік, вся програма була розрахована на 3 роки. Тут читались лекції на політичні та педагогічні теми, вивчався досвід майстрів педагогічної праці,

\footnotetext{
${ }_{33}^{33}$ Ігнатенко П. Вимогливо і принципово // Радянська освіта, 1985. № 53. С. 1.

${ }^{34}$ Звіт про навчально-виховну роботу Березнеговатської середньої школи Миколаївської області за 1953/1954 р. // Державний архів Миколаївської області (ДАМО) Ф. Р-2817. Оп. 1. Спр. 223. Арк. 35.

${ }^{35}$ Нечипорук 3.С. Піклування про вчителя-важливіший обов'язок профспілкових організацій // Радянська школа. 1960. № 1. С. 9-11.
} 
проводили зустрічі з ветеранами праці, Героями Радянського Союзу, Героями Соціалістичної Праці, новаторами виробництва, молоді учителі відвідували уроки та виховні заходи. Організовані індивідуальні та групові консультації кращих педагогів району. Практикувались заняття у школі досвідчених педагогів, заняття у формі екскурсій рідним краєм, місцями «бойових і трудових звершень народу».

Окрім шкіл молодого учителя працювали й клуби молодого учителя. Одним із таких був клуб «Евріка», який працював у Сахнівській середній школі Корсунь-Шевченківського району. Його метою стало розширення світогляду молодих педагогів, ознайомлення їх із досягненнями науки, техніки, літератури і мистецтва. Іншою формою роботи з молодими фахівцями стали наставництво та стажування. До учителів прикріпляли керівників, які допомагали їм у плануванні роботи, підготовці до уроків, лабораторних і практичних занять. Їх супроводжували фахівці-методисти та викладачі педагогічних інститутів.

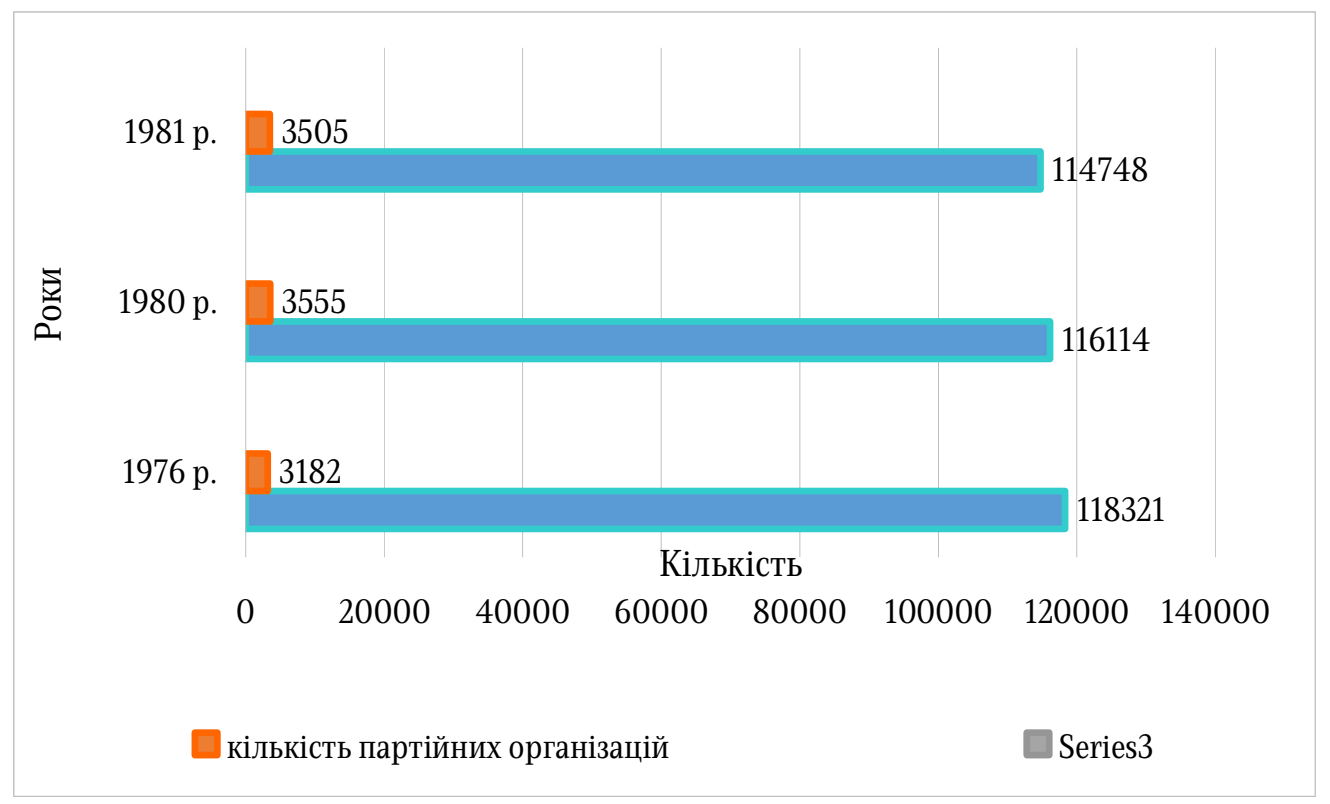

Рис. 1. Кількість партійних організацій і комуністів у загальноосвітніх школах протягом 1976-1981 рр. ${ }^{36}$

3 метою зосередження роботи педагога «у полі зору громадськості» проводили районні, міські, обласні огляди діяльності молодих учителів. Їх метою стало виявлення педагогів-майстрів, поширення їх досвіду, сприяння ширшому долученні до участі в суспільно-політичному житті. Цим керував оргкомітет, до складу якого входили працівники органів народної освіти, комітетів профспілки та комсомольських органів. Досвід їх роботи знайшов відображення - в естафеті-альбомі під девізом «I праця переростає у красу», присвячений 60-річчю «Великого Жовтня». Близько 500 учителів Полтавщини були народними депутатами місцевих рад, багато педагогів-комсомольців членами районних комітетів комсомолу». Кращих учителів нагороджували пам'ятними

\footnotetext{
${ }^{36}$ Діаграма складена автором за: Центральний державний архів громадських обєєднань України (ЦДАГО України). Ф. 1. Оп. 32. Спр. 2093. Арк. 13
} 
подарунками, грамотами і туристичними путівками ${ }^{37}$. Метою цих заходів стало вироблення «правильного світогляду» та долучення педагогів до лав комуністичної партії. Протягом 1976-1981 рр. кількість партійних організацій і комуністів у загальноосвітніх школах була такою (див. рис. 1).

Як показує діаграма, протягом 1976-1981 рр. кількість партійних осередків збільшилася із 3182 до 3505 тис., а комуністів, прийнятих до лав зменшилося: у 1976 р. 118321, 1980 р. - 116 114, у 1981 р. - 114748 осіб відповідно ${ }^{38}$.

Але не всі розуміли навіщо збирали зї̈ди та наради. Як згадував Є. Сверстюк:

«...в їхній хаті квартирували дві вчительки. Під час того гостювання... роля режисера випала на Петра, великого жартівника і нев'янучого оптиміста. Він зумів навіяти уявлення, що не в усіх школах конференція відбувається в той самий час». Тобто, населення продовжувало зберігати власні традиції і воно розуміло, що подібні зібрання носять формальний характер ${ }^{39}$. у березні 1965 р. йому випала нагода виступити перед великою вчительською аудиторією у Нововолинську. Якби не звичка порушувати межі забороненої зони, він би почитав свою доповідь про естетичне виховання у школі в межах дозволеного. Утім щось раптом спокусило його порушити тему, яку так скоромовкою назвав студент Ізотов: «Лож! Лож! До якого часу!». Коли він заговорив про похмуру естетику сталінських «закликів Броуді», будинків обкомів, куди ніколи не заглядає сонце і де ніхто не достукується в дубові двері, запанувала тиша... Коли заговорив про заляканого радянського вчителя, про конюнктурну фальсифікацію Шевченка і про тенденцію тлумачити «сім'ю вольну, нову» як мрію поета про «сім’ю народів» СРСР, про перетворення авторки «Лісової пісні» на революціонерку тощо, то напруга зросла. У президію до секретаря Волинського обкому партії почали надходити записки із запитаннями, чи це доповідь від ЦК партії, чи просто від особи старшого наукового співробітника Інституту психології. Після бурхливих оплесків демократичного крила жодна людина не наважилася підійти до Є. Сверстюка, і він зрозумів, що в їхніх очах той нагадував студента Ізотова, який порушив правила гри - гри в офіційний обмін офіційними думками на офіційній конференції. Того самого року мені перекрили захист дисертації, а через сім років судили, зокрема за висловлювання на адресу влади» ${ }^{40}$.

Є. Сверстюк не розумів, як можна було вчителеві пройти через той частокіл, щоб не повалити його й легко відбутися? Передусім треба було знати, хто його ставить і нащо, тобто критично й навіть опозиційно сприймати «філософію діялектичного матеріялізму». «Але боронь Боже сперечатися з нею вголос! Соціялізму без музики ніякими гарматами не встановити. Хто це міг розуміти, окрім якихось старих безробітних інтелігентів?» ${ }^{41}$

Учителі-чоловіки, які перебували у запасі мали періодично проходити військову перепідготовку, яка зводилася до читання лекцій про дії у наступальному бою. Вони були настільки нецікавими, що молодий учитель малював карикатури на керівництво. Секретар

\footnotetext{
${ }^{37}$ Про поліпшення роботи з молодими вчителями // Збірник наказів та розпоряджень Міністерства освіти Української РСР. 1978. № 2. С. 13-20.

${ }^{38}$ Записка и справки о реформе 1984 г. // ЦДАГО України. Ф. 1. Оп. 32. Спр. 2093. Арк. 13.

${ }^{39}$ Сверстюк Є.О. На полі чести: У 2 кн. Кн. І: Невже то я? / Упорядник Олексій Сінченко. Київ: ТОВ «Видавництво “Кліо"», 2015. С. 37.

${ }^{40}$ Сверстюк Є. О. Вказана праця. С. 97.

${ }^{41}$ Ibid. C. 120.
} 
райкому впізнав себе і вирішив приїхати на іспит з перевіркою, чи правильно учитель навчив дітей ідеологічно мислити і передавати власні думки на папері. Коли той взяв твір одного із учня, то не зрозумів почерк, попрохавши педагога почитати. Останній побачив результат свої діяльності і почав імпровізувати, щоб вийшов «правильний твір», а діти сиділи і посміхалися, ще більше переконавшись у тому, що учитель «свій» ${ }^{42}$.

Поряд із декларованими гаслами до педагогів з боку держави було принизливе ставлення. Його розцінювали як боржника за те, що він живе у країні Рад. Тому, вимагали від нього відповідного служіння. У матеріалах відділу шкіл ЦК КП(б) за 1952 р. зазначалося, що у селі Барилів Лопатинського району прокурор П. примусив учителів по черзі чергувати на конюшні у колгоспі імені Кірова - слідкувати за правильністю видачі кормів для коней по 4 години. Міністерство освіти УРСР у кінці 1954 р. зробило спробу унормувати позаурочну діяльність педагогів, заборонивши використання учителів у вихідні та святкові дні для роботи в школі, колективне відвідування учнями у вихідні дні кіно, театрів, виставок, проведення з ними екскурсій; використання класних керівників для збору плати за навчання, коштів на придбання підручників та зошитів ${ }^{43}$. Хоча цього не виконувалося.

Учителів звинувачували і в неякісній роботі, яка полягала у формальному підході до власної діяльності. Недивно, що у вчительських нарадах західних, Чернівецької, Закарпатської, Ізмаїльської областей УРСР брали участь педагоги східних областей УРСР, які ділилися власним досвідом роботи. Вони продемонстрували досягнення передових шкіл і учителів, які мали «високі показники у боротьбі за виконання рішень ЦКВКП(б) і ЦК КП(б)У 3 ідеологічних питань. Учасники відмітили велику допомогу у цьому піонерських та комсомольських організацій». Про недоліки у роботі педагогів теж відзначили. Це стало свідченням номінального функціонування тут «білышовицьких порядків» і продовження існування тої школи, яка існувала ${ }^{44}$.

Євген Сверстюк писав, що обов'язковим стереотипом радянської дійсності мало бути «...клясове чуття. І поет, і професор, і агітатор повинні знати, за що гладять, а за що шкіру деруть». Існував ще такий стереотип, як боротьба двох культур у кожній національній культурі. Уже школярі знали: потрібно, щоб Шевченко ворогував із Кулішем, Франко - із Грушевським, Грабовський - із Грінченком, Леся Українка - із своєю матір'ю Оленою Пчілкою. Відчували, що то неправда, але знали, що вона обов’язкова. Література створила стереотип заляканого та приниженого священника і багато людей не могли собі уявити, що то ж, по суті, - учитель народу. Стереотипами офіційної слави стали поети, «співці партії». Існував і стереотип боязкого селянина, що його заганяють до колгоспу. Про мудрого вождя можна було говорити з урочистою інтонацією. Неодмінним був стереотип «старшого брата», який «безкорисливо допомагав» молодшому. Утім і молодший брат допомагав старшому, скажімо «визволяти трудящих» інших країн. Вони - «воїнивизволителі». Німець - дурний і злий, бандерівець - із тризубом і ножем, куркуль - iз обрізом і 3 хитруватою посмішкою, палій нової війни 3 «котелком» на голові - made in $\mathrm{USA} »^{45}$.

\footnotetext{
${ }^{42}$ Ibid. C. 122-123.

${ }^{43}$ Лікарчук І.Л. Міністри освіти України: монографія: у 2 т. Т.2. (1943-2007 рр.). Київ: Видавництво «Ешке 0.М.», 2010. С. 122.

${ }^{44}$ Про підсумки січневих нарад учителів та завдання відділів народної освіти і шкіл // Збірник наказів та розпоряджень Міністерства освіти Української РСР. 1950. № 2. С. 12-17.

${ }^{45}$ Сверстюк Є.О. Вказана праця. С. 119.
} 
Саме це повинні були виражати учителі й представники інтелігенції в цілому. Тобто, паралельно із офіційними поглядами існували інші - опозиційні. О. Бажан зазначає про участь педагогів у розповсюдженні самвидавничої літератури, засудженні «возз'єднання» України з Росією, штучного голоду 1932-1933 рр., відсутності демократичних свобод, подій 1968 р. у Чехословаччині, дисидентському русі ${ }^{46}$.

Отже, громадсько-політична активність учителів у 1950-х - 1980-х рр. обумовлювалася обставинами часу. Безпосередня власна педагогічна діяльність, яка була спрямована на удосконалення вивченого, почутого й адресувалась своїм колегам, учням і батькам задля їх «загартування». Учителі були переобтяжені різними видами роботи, безпосередньо не пов'язані з навчальним процесом. Несприйняттям радянської влади вирізнявся західноукраїнський регіон, де до середини 1950-х років ще діяло українське націоналістичне підпілля. I населення пам'ятало життя за Польщі, Румунії та Угорщини. Тут з більшою повагою ставилися до учителів, які окрім свого фахового рівня, відрізнялися й набожністю. Шкільна інтелігенція власний потенціал демонструвала на підприємствах, колгоспах, радгоспах, що виявлялося у агітаційних кампаніях і безпосередній роботі у них. Пізніше педагоги долучались і до опозиційної діяльності: опосередкованої (знайомились із літературними творами) та безпосередньої. Таким чином, влада намагалася через діяльність педагогів залучити якомога більше населення до своїх заходів.

\section{Olga Lavrut}

\section{Social and political activity of school teachers of the USSR in 1950-1980}

Abstract: Teaches in the Soviet state was considered in the focus of the mouthpieces of the ideology of the ruling party, which shaped the worldview of the younger generation. It also emerged from the standpoint of personnel policy, which was clearly regulated and centralized. At teachers 'congresses, congresses of public education workers, and commissions on education, issues of various spheres of teachers' lives were discussed and their participation in them was emphasized. Another area of their activity was joining the election campaigns. They acted as both agitators, emphasizing the peculiarities and advantages of the Soviet system, and candidates for deputies. Teachers also took part in public events dedicated to the anniversaries of the life and work of cultural figures. Teachers were agitators, members of the Pedagogical society for the dissemination of political and scientific knowledge. In the regions of the Ukrainian SSR there were branches of the Pedagogical Society, which were called to carry out political and educational work among the pedagogical community.

Teachers were engaged in propaganda activities in collective farms, enterprises, organizations. Teachers at enterprises, fields and farms of collective and state farms gave lectures and explained the decisions of the sessions of the Supreme Soviet of the USSR, the decisions of the plenums of the Central Committee of the CPSU, read reports on the international situation. This took place under the slogans of political and socio-economic

${ }^{46}$ Бажан О.Г., Данилюк Ю.З. Український національний рух: основні тенденції і етапи розвитку (кінець 1950-х - 1980-ті роки). Київ: Рідний край, 2000. 232 с. 
progress of the USSR. On the one hand, these measures demonstrated the integration of everyone into state-building processes, and on the other hand, they separated teachers from their immediate affairs. Teachers were not blind executors of all assignments, they joined the opposition activities: indirect and direct. Thus, the authorities tried to involve as many people as possible in their activities through the activities of teachers. In general, the participation of teachers $n$ public activities was one of the indicators of their work.

Keywords: elections, social and political activity, teachers, politics, society, Ukrainian SSR, school 